\title{
First case of Trichodectes pinguis (Phthiraptera: Ischnocera: Trichodectidae) on a Bear (Ursus arctos) in Turkey
}

\section{Türkiye’de Bir Ayıda (Ursus arctos) ilk Trichodectes pinguis (Phthiraptera: Ischnocera: \\ Trichodectidae) Olgusu}

\section{Bilal Dik 1 , Özlem Orunç Kılınç²}

${ }^{1}$ Selçuk Üniversitesi Veteriner Fakültesi, Parazitoloji Anabilim Dalı, Konya, Türkiye

${ }^{2}$ Yüzüncü Yıl Üniversitesi Özalp Meslek Yüksekokulu, Van, Türkiye

\section{ABSTRACT}

This study was conducted to provide morphological characters of Trichodectes pinguis Burmeister, 1838 that was found on a European brown bear (Ursus arctos Linnaeus) that was found injured in the Van province, eastern Turkey. Three lice specimens were collected from the bear, and they were identified as T. pinguis. The morphological characteristics of this species were provided in this study. T. pinguis was reported for the first time in Turkey. (Turkiye Parazitol Derg 2015; 39: 313-5)

Keywords: Trichodectes pinguis, Bear, Phthiraptera, Ischnocera, Turkey.

Received: 10.12.2014 Accepted: 16.06.2015

\section{ÖZ}

Bu makale Doğu Türkiye'de, Van yöresinde yaralı olarak bulunan bir Bozayıdan (Ursus arctos, L.) toplanan Trichodectes pinguis Burmeister, 1838'in morfolojik özellikleri hakkında bilgi vermek amacıyla hazırlanmıştır. Ayıdan üç adet bit toplanmış ve bitler T. pinguis olarak teşhis edilmiştir. Bu makalede bu türün morfolojik özellikleri hakkında bilgi verilmiştir. T. pinguis Türkiye'den ilk kez bildirilmektedir. (Turkiye Parazitol Derg 2015; 39: 313-5)

Anahtar Kelimeler: Trichodectes pinguis, Ayı, Phthiraptera, Ischnocera, Türkiye.

Geliş Tarihi: 10.12.2014

Kabul Tarihi: 16.06.2015

\section{INTRODUCTION}

Bears belong to the family Ursidae, and only the European brown bear (Ursus arctos Linnaeus, 1758) is found in Turkey (1). Chewing lice belong to the suborders Ischnocera and Amblycera and the order Phthiraptera and live on birds and mammals. They feed on the feathers, dead skin, and skin products of their hosts. They generally cause subclinical infestation on their hosts if found in fewer numbers; however, when present in large numbers on the hosts, they can cause severe irritation. More than 6,000 lice species have been described to date. However, 4,500 out of them are valid species, and a small portion of the lice species occur on mammalian hosts. Most of the lice species found on the mammalian hosts belong to the family Trichodectidae.
There are eight species in the genus Trichodectes, and Trichodectes pinguis Burmeister was found on European brown bear in 1838 (2).

In his monograph about lice belonging to the superfamily Trichodectoidea, Kéler (3) provided detailed information regarding the louse species of the family. He recorded $T$. pinguis in the Ursodectes genus as $U$. pinguis and introduced the morphological characters of its female but that of males still remained unknown. There are a few studies regarding lice species occurring on bears worldwide, and few studies provided information on the morphological characteristic of T. pinguis (3-5). This species was detected on the North American black bear (Euarctos americanus) as $T$. pinguis euarctidos; subspecies of $T$. pinguis (5) on the

Address for Correspondence / Yazışma Adresi: Dr. Bilal Dik. E.mail: bdik2004@yahoo.com DOI: 10.5152/tpd.2015.4040

CCopyright 2015 Turkish Society for Parasitology - Available online at www.tparazitolderg.org

CTelif hakkı 2015 Türkiye Parazitoloji Derneği - Makale metnine www.tparazitolderg.org web sayfasından ulaşılabilir. 

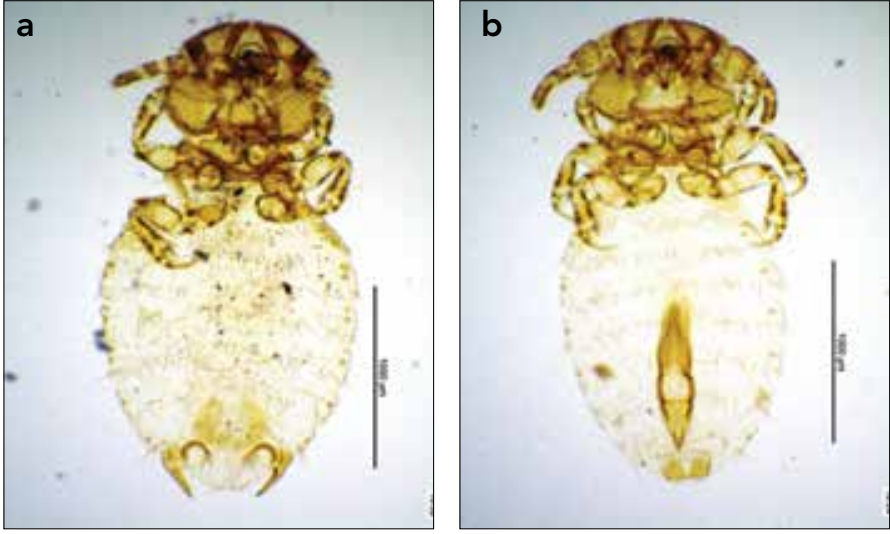

Figure 1. a, b. Trichodectes pinguis, female (a). Trichodectes pinguis, male (Head is anteriorly concave), (b), original

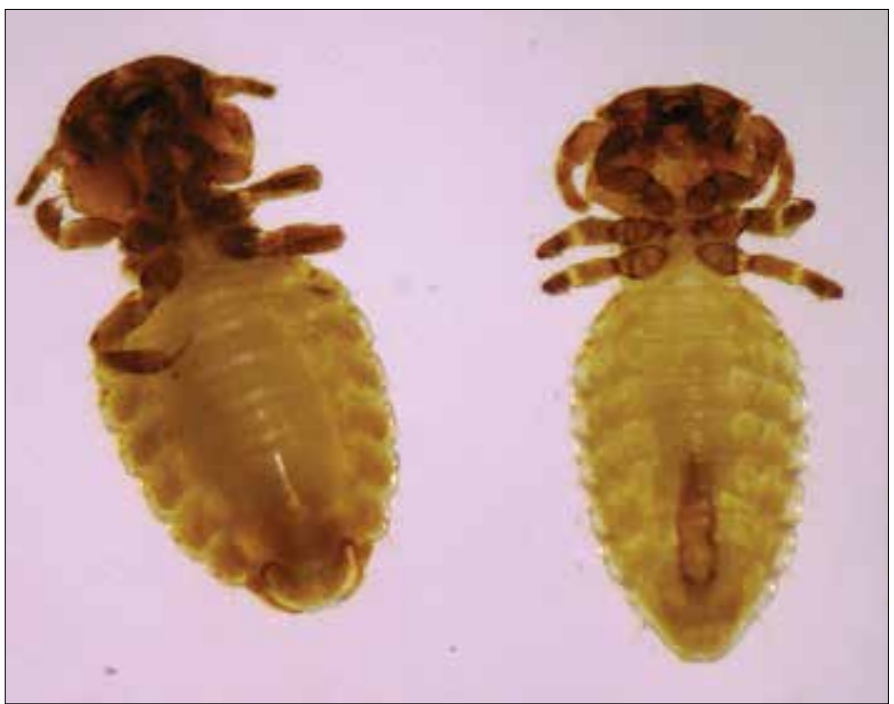

Figure 2. Trichodectes pinguis, female (at left), male (Head is slightly convex) (at right), original

brown bears (U. arctos) in Europe by Burmeister (1838) and Werneck (1948); and from a Himalayan black bear (U. thibetanus) in the zoo in Paris by Neumann (1913) (6). Rogers and Rogers (6) reported that this species had been found on wild black bears in Michigan and Minnesota. There are also reports of $T$. pinguis having been located on an Asian black bear (Himalayan black bear: U. thibetanus) in the Kyushu Island, Japan (7).

No reports have been found wherein $T$. pinguis had occurred on a bear in Turkey. This study was conducted to provide information regarding some morphological characteristics of $T$. pinguis that was found on a bear in the Van province, eastern Turkey.

\section{CASE REPORT}

A six-month-old male brown bear, which was found injured by villagers in a forest near Saray town, Van City, eastern Turkey on April 16, 2014, was brought to the Directorship of Wild Animal Protection of the University of Yüzüncü Yil. Despite all strenuous medical treatments, the bear died 2 days later. Lice infestation was detected on the bear during ectoparasitic examination, and three lice specimens were collected. They were preserved in a vial in 70\% ethanol. The lice specimens were observed through a stereo zoom micro-

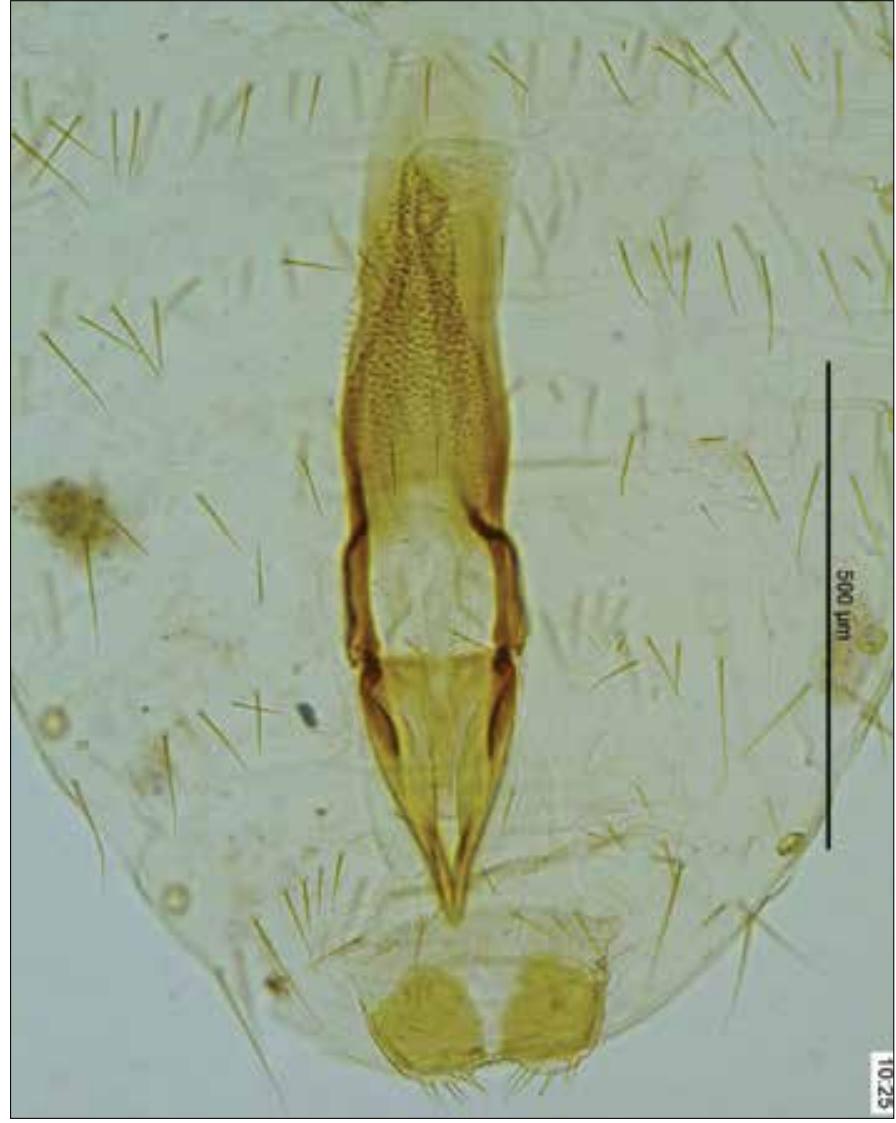

Figure 3. Trichodectes pinguis, male genitalia, original

scope, and one of the two females and one male were transparented in $10 \% \mathrm{KOH}$ for $24 \mathrm{~h}$. The samples were washed in distilled water and transferred to $70 \%$ and $99 \%$ ethanol, respectively. They were mounted on slides in Canada balsam, examined under the binocular microscope (Leica DM750), and identified as T. pinguis.

\section{T. pinguis Burmeister, 1838}

Materials Studied: one female and one male

Female: Head is relatively wider than the length and originally smooth in anterior but slightly rounded on the slide-mounted specimen (Fig. $1 \mathrm{a}$ and 2). The anterior part of the head is heavily pigmented. The antenna has three segments, and the first of these is slightly wider than the others. The mandibula is well developed; eyes obviously are prominent and have a short seta.

The thorax is short and narrower than the head. Prothorax is trapezoidal and anteriorly narrow. The pterothorax is narrower than the prothorax in length. The legs are thin and short and have a fine claw.

The abdomen is relatively long and wide, and there is only one seta order on the sternits. It has one stout and a sharp spiculum on each side of the posterior end.

Male: It resembles to female. Head is normally slightly convex but on the mounted specimen, it is anteriorly concave (Fig. 1b and 2). The antenna is well developed; the first segment is obviously larger than the other segments. Male genitalia are as in shown in Fig. 3. 
Table 1. Some measurements of Trichodectes pinguis

\begin{tabular}{|l|c|c|}
\hline & Female (n: 1) & Male (n: 1) \\
\hline Head Length: & $0.61 \mathrm{~mm}$ & $0.55 \mathrm{~mm}$ \\
\hline Head Width: & $0.79 \mathrm{~mm}$ & $0.74 \mathrm{~mm}$ \\
\hline Thorax Length: & $0.42 \mathrm{~mm}$ & $0.43 \mathrm{~mm}$ \\
\hline Thorax Width: & $0.64 \mathrm{~mm}$ & $0.62 \mathrm{~mm}$ \\
\hline Abdomen Length: & $1.59 \mathrm{~mm}$ & $1.56 \mathrm{~mm}$ \\
\hline Abdomen Width: & $1.31 \mathrm{~mm}$ & $1.14 \mathrm{~mm}$ \\
\hline Total Length: & $2.59 \mathrm{~mm}$ & $2.55 \mathrm{~mm}$ \\
\hline
\end{tabular}

Some measurements of female and male are given in Table 1.

\section{DISCUSSION}

There are a few studies that are conducted on lice of either birds or mammals in Turkey $(8,9)$. The numbers of studies performed on lice of wild birds have been gradually increasing for 10 years. In contrast, no study on lice occurring on wild mammals, except hares (Lepus europaeus) (10-12) and wild boars (Sus scrofa) (13), in Turkey were found. The researchers recorded Haemodipsus lyriocephalus (Burmeister, 1839), Haemodipsus setoni Ewing, 1924. (10, 11), and Haemodipsus leporis Blagoveshtchensky, 1966 (12) on hares; in the other study (13), the researchers detected Haematopinus suis Linnaeus, 1758 on a boar for the first time in Turkey. There is no more data available regarding lice on wild mammals in Turkey. Moreover, it has been difficult to conduct a study on lice species on wild mammals because either the capturing of wild mammals is very difficult and dangerous or is forbidden; this is similar as the hunting of many wild mammals is also forbidden in Turkey. Furthermore, there are few researchers who have been studying Phthiraptera, particularly Amblyceran and Ischnoceran species, parasitizing on wild birds in the country. No specialist who has been working on Phthiraptera has found anything on the wild mammals in Turkey. For these reasons, almost all of the lice fauna occurring on wild mammals are yet unknown. In this case, three T. pinguis specimens were collected on a wild bear in the Van province. The number of the lice specimens was rather few for a bear. In fact, several more lice could have been collected from the bear. However, it could not be achieved because of the hide of the bear was densely covered with hair. Keler (3) measured a total length of a female T. pinguis as $2.05 \mathrm{~mm}$, whereas Hopkins (5) stated that it could be $2.60 \mathrm{~mm}$. It has been observed that morphological characters of the female $T$. pinguis analyzed in this study are the same as those found by the authors (3-5) above. The total length of the female T. pinguis analyzed is $2.59 \mathrm{~mm}$, which is longer than those observed by Keler (3) and similar to Hopkins (5).

\section{CONCLUSION}

T. pinguis was recorded for the first time in Turkey. Further studies should detect lice fauna on mammalian hosts in Turkey.

Ethics Committee Approval: Ethics Committee Approval was not received due to the nature of the study.

Informed Consent: Informed Consent is not required in this study
Peer-review: Externally peer-reviewed.

Author contributions: Consept - B.D., Ö.O.K.; Design - B.D., Ö.O.K; Supervision - B.D.; Funding - B.D.; Materials - B.D., Ö.O.K.; Data Collection and/or Processing - B.D., Ö.O.K.; Analysis and/or Interpretation - B.D.; Literature Review - B.D.; Writer - B.D.; Critical Review - B.D.

Conflict of Interest: No conflict of interest was declared by the authors.

Financial Disclosure: The authors declared that this study has received no financial support.

Etik Komite Onayı: Çalışmanın yapısından dolayı etik kurul onayına gerek duyulmamıştır.

Hasta Onamı: Bu çalışma için hasta onamına gerek yoktur.

Hakem Değerlendirmesi: Dış Bağımsız.

Yazar Katkıları: Fikir - B.D., Ö.O.K.; Tasarım - B.D.,Ö.O.K.; Denetleme B.D; Kaynaklar - B.D.; Malzemeler - B.D., Ö.O.K.; Veri Toplanması ve/veya işlemesi - B.D., Ö.O.K.; Analiz ve/veya Yorum - B.D.; Literatür taraması B.D.; Yazıyı Yazan - B.D.; Eleştirel İnceleme - B.D.

Çıkar Çatışması: Yazarlar çıkar çatışması bildirmemişlerdir.

Finansal Destek: Yazarlar bu çalışma için finansal destek almadıklarını beyan etmişlerdir.

\section{REFERENCES}

1. Demirsoy A. Yaşamın Temel Kuralları. Omurgalılar/Amniyota (Sürüngenler, Kuşlar ve Memeliler) Cilt-II I/ Kısım-II. Beşinci Baskı. Meteksan AŞ; Ankara; 2003.

2. Price RD, Hellenthal RA, Palma RL, Johnson KP, Clayton DH. The Chewing Lice: World checklist and biological overview. Illinois Natural History Survey Special Publication; 24. x + 501 pp, 2003.

3. Kéler S. Baustoffe zu einer Monographie der Mallophagen. I. Teil: Überfamilie der Trichodectoidea. Nova Acta Leop-Carol 1938; 5: 395-467.

4. Séguy E. Insectes Ectoparasites (Mallophages, Anoploures, Siphonaptéres), 43. Faune de France. Paul Lechevalier et Fils; Paris; 1944.

5. Hopkins GHE. Notes on some Mallophaga from bears. The Entomologist 1954; 87: 140-6.

6. Rogers LL Rogers SM. Parasites of Bears: A review. Third International Conference on Bears. Bears. Pelton MR, Folk GE, Lenfer JW, editors. Morges, Switzerland; 1976; p. 411-30.

7. Yokohata Y, Fujita O, Kamiya M, Fujita T, Kaneko K, Ohbayashi M. Parasites from the Asiatic Black Bear (Ursus thibetanus) on Kyushu Island, Japan. J Wild Dis 1990; 26: 137-8. [CrossRef]

8. Merdivenci A. Türkiye'nin Entomolojik Coğrafyası. Unat EK, Yaşarol Ş, Merdivenci A, Editors. Türkiye'nin Parazitolojik Coğrafyası. Ege Üniversitesi Tıp Fakültesi Yayınları No: 42; Ege Üniversitesi Basımevi; İzmir; 1965.

9. Inci A, Yıldırım A, Dık B, Düzlü Ö. Current knowledge of Turkey's louse fauna. Turkiye Parazitol Derg 2010; 34: 212-20. [CrossRef]

10. Dik B, Uslu U. Haemodipsus Species Occurring on Hares (Lepus eurapeus, L.): Two New Species in Turkish Lice Fauna. Türkiye Parazitol Derg 2007; 31: 119-22.

11. Dik B, Uslu U. Prevalence of Haemodipsus (Anoplura: Polyplacidae) species found on hares (Lepus europaeus L.) in Konya Province, Turkey.Türkiye Parazitol Derg 2008; 32: 146-8.

12. Dik B, Uslu U. Haemodipsus leporis Blagoveshtchensky, 1966 (Phthiraptera: Anoplura: Polyplacidae) on a Hare (Lepus europaeus, L.): new record for Turkish Phthiraptera fauna. Turkiye Parazitol Derg 2012; 36: 260-3. [CrossRef]

13. Girişgin $O$, Girişgin AO, Sönmez $F$, Akyol ÇV. Occurrence of Haematopinus suis Linnaeus, 1758 (Insecta, Anopluridae) on a wild boar (Sus scrofa). Turk J Vet Anim Sci 2009; 33: 529-30. 